\title{
Tantangan Pembinaan Keagamaan melalui Media Sosial pada Masyarakat Lereng Merapi di Masa Pandemi COVID 19
}

\author{
Azizah Herawati \\ Kantor Kementerian Agama Kabupaten Magelang, Indonesia \\ azizahhera75@gmail.com
}

\begin{abstract}
This paper describes the phenomenon of using social media as a means of religious development in the era of the COVID-19 pandemic. The social media access that by Islamic Religious Counselors has not been effective during the COVID-19 period. This paper describes the various obstacles that challenging for Islamic Religious Counselors in carrying out religious development in the Merapi slope community by using social media facilities. We used qualitative approach to collect the data. We did participatory observation, in-depth interviews, discussions and documentation used and then described. The results show that the obstacles encountered in the process of religious development for the Merapi slope community by using social media as a means of religious development during the COVID-19 pandemic are such as limited facilities, lack of ability to access social media and lack of public interest in the media. This situation will be different from other regions with access and supporting facilities, because there are several factors that cause it, such as education, skill and the economy
\end{abstract}

Keywords: Counselor, merapi slope community, COVID-19, social media 


\begin{abstract}
Abstrak
Tulisan Ini menjelaskan tentang fenomena penggunaan media sosia sebagai sarana pembinaan keagamaan di era pandemi COVID-19. Penggunaan media sosial oleh Penyuluh Agama Islam belum efektif pada masa COVID-19. Tulisan ini menjelaskan beragam kendala yang menjadi tantangan para Penyuluh Agama Islam dalam melakukan pembinaan keagamaan pada masyarakat lereng merapi dengan menggunakan sarana media sosial. Metode deskriptif kualitatif melalui observasi partisipatif, wawancara mendalam, perbincangan dan dokumentasi yang digunakan lalu dideskripsikan. Hasilnya menunjukkan bahwa kendala yang ditemui dalam proses pembinaan keagamaan masyarakat lereng Merapi dengan menggunakan media sosial sebagai sarana dalam pembinaan keagamaan selama pandemi COVID 19 adalah seperti terbatasnya fasilitas, minimnya kemampuan dalam akses media sosial dan kurangnya minat masyarakat terhadap media. Keadaan ini akan berbeda dengan daerah lain yang akses dan sarana mendukung, karena ada beberapa faktor yang menyebabkan seperti pendidikan, keterampilan dan ekonomi
\end{abstract}

Kata kunci: pandemic, Penyuluh, masyarakat lereng Merapi, media sosial

\title{
Pendahuluan
}

Selama pandemi COVID 19, kegiatan di masjid dan mushalla juga dikendalikan bahkan dihentikan, terutama yang berada di pusat jalan utama di Magelang, Indonesia. Terlebih lagi adanya kenaikan penderita COVID 19 gelombang kedua pasca kebijakan new normal diterapkan (Wening, 2020), praktis tidak ada lagi kegiatan rutin keagamaan yang berlangsung. Kondisi tersebut menyebabkan masyarakat merasa gersang secara spiritual. Mereka merindukan pesan-pesan agama melalui dakwah yang disampaikan oleh para penyuluh agama yang selama ini membimbing mereka secara langsung atau tatap muka.

Realitas tersebut menyadarkan para penyuluh agama memanfaatkan media sosial sebagai media transfer pesan keagamaan. Media sosial mempermudah seluruh lapisan masyarakat dalam berkomunikasi, menjalin silaturahim, sehingga hubungan antar sesama menjadi terasa dekat (Taufiq, F. \& Utama, 2018). Rubawati (2018) menjelaskan media baru berupa internet berpengaruh dalam menyampaikan pesan-pesan keagamaan kepada mad'u atau obyek dakwah. Da'i selaku subyek dakwah tidak lagi menjadi faktor utama dari diterimanya pesan-pesan dakwah secara maksimal oleh mad'u (obyek dakwah). Melalui media sosial, obyek dakwah tidak hanya menerima pesan dakwah secara pasif, namun mereka secara aktif mengolah pesan yang diterima dan membagikannya lagi melalui media sosial yang dimilikinya. Obyek dakwah secara aktif mampu memanfaatkan media sosial sebagai sarana dalam menerima pesan keagamaan dari subyek dakwah dan mampu 
mengolah pesan untuk disampaikan ke pihak lain melalui media sosial yang dimilikinya. Cyberdakwah diharapkan mampu menjawab berbagai tantangan dan permasalahan (Rustandi, 2019). Melalui media sosial, mestinya masyarakat Magelang merasa nyaman dan puas dengan adanya fasilitas yang disajikan melalui media sosial sebagai sarana pembinaan keagamaan di era pandemi. Tetapi kondisi tersebut tidak terjadi di Kawasan lereng Merapi, sebuah daerah pedesan dan pedalaman di Magelang. Kegiatan transfer pesan keagamaan yang dilakukan oleh Penyuluh agama melalui media sosial tidak direspon baik oleh masyarakat. Ironisnya, para penyuluh agama pun bereaksi yang sama. Padahal, media sosial dianggap sebagai satu-satunya alternatif penyelesaian masalah dari adanya keluhan masyarakat terhadap kebutuhan ruhaniah.

Penelitian yang berkaitan dengan media sosial dan penggunaannya dalam pembinaan masyarakat sudah banyak dilakukan. Jika dibandingkan dengan penelitian yang sudah ada terkait penggunaan media sosial dan segala bentuk literasi digital yang dilakukan pada penelitian lain, penelitian ini tentu berbeda karena tidak menempatkan media sosial sebagai primadona dan segala-galanya. Pada penelitian ini justru muncul tantangan baru kepada pembina dan pendamping masyarakat dalam hal keagamaan untuk memunculkan strategi baru namun tetap mampu mencegah penularan virus COVID-19 di era pandemi.

\section{Metode}

Penelitian ini menggunakan metode deskriptif kualitatif, sebuah penelitian yang menggunakan gambaran peristiwa atau fenomena yang ada dengan paparan berupa data yang berbentuk informasi dan kata-kata (Moloeng, 2013). Adapun tehnik pengumpulan data dalam penelitian ini adalah melalui observasi berperan serta (participant observation), wawancara mendalam (depth interview), perbincangan (daily course method) serta dokumentasi. Subyek dari penelitian ini adalah Penyuluh Agama Islam nonPNS (PAI nonPNS) Kecamatan Dukun Kabupaten Magelang. Sebagai data pendukung, peneliti juga mencari data, komentar, kritik dan saran berdasarkan pengamatan dari pihak-pihak yang berhubungan langsung dengan para penyuluh. Pihak-pihak tersebut antara lain Kepala Kantor Urusan Agama (KUA) Kecamatan Dukun Magelang sebagai koordinator dan penanggung jawab di tingkat kecamatan, tokoh agama dan tokoh masyarakat serta beberapa anggota jamaah binaan dari PAI nonPNS yang berada di 
wilayah lereng Gunung Merapi, Kecamatan Dukun, Kabupaten Magelang, Jawa Tengah, Indonesia. Tehnik pengumpulan data adalah pertama adalah dengan observasi partisipatif, dimana peneliti terlibat langsung dalam kegiatan dari subyek yang akan diteliti (Khilmiyah, 2016). Selain melakukan pengamatan secara langsung dalam berbagai kegiatan, peneliti juga mengamati kegiatan subyek melalui pengamatan dalam obrolan dan aneka postingan di whatsapp group. Kedua, melalui wawancara mendalam (depth interview) (Herawati, 2017; Mulyana, 2013). Ketiga, melalui metode perbincangan (daily course method). (Ismail, 2015). Keempat, teknik dokumentasi.

Analisis data dibagi menjadi dua tahapan, yaitu analisis ketika di lapangan dan analisis pasca di lapangan. Pertama, analisis ketika di lapangan. Yakni analisis ketika melaksanakan penelitian di lapangan akan dilakukan teknik induksi, yaitu analisis terhadap data yang diperoleh pada penulisan laporan sementara yang ada di fieldnotes. Hasil analisis dikembangkan untuk dilakukan penelitian lagi untuk memperoleh jawaban. Pola ini disebut snow ball (bola salju) yaitu menverifikasi, mengubah, dan memperluas informasi dari subyek penelitian yang satu ke subyek yang lain sampai jenuh, sampai tidak ada jawaban lagi. Kedua, analisis pasca di lapangan, dilakukan dengan beberapa langkah mulai dari memeriksa keabsahan data, menelaah seluruh data yang ada dalam fieldnotes atau data yang diperoleh dari penelitian, mereduksi dan mengkategori data serta menemukan konsep-konsep lokal serta menafsirkan dan menyimpulkan terhadap data yang sudah diuraikan, yaitu data yang sudah terkategorikan dan hubungan antar konsep sudah dilakukan (Ismail, 2015).

\section{Media Sosial sebagai Sarana Pembinaan Keagamaan Era COVID 19}

Media sosial menurut Kamus Besar Bahasa Indonesia (KBBI) adalah "Laman atau aplikasi yang memungkinkan pengguna dapat membuat dan berbagi isi atau terlibat dalam jaringan sosial" (KBBI V Online). Media sosial sebagai sekumpulan aplikasi berbasis internet yang dibangun berdasarkan ideologi dan teknologi Web 2.0 untuk memudahkan dalam penciptaan dan tukar menukar data (Kaplan, 2010). Media sosial terdiri dari dua kata, yaitu media dan sosial. Media berarti sebuah alat yang digunakan untuk berkomunikasi dan sosial berarti suatu aksi atau interaksi dari seseorang terhadap masyarakat di sekelilingnya. Media sosial merupakan media daring yang digunakan sebagai alat untuk bertukar informasi melalui berbagai fitur 
dengan menggunakan jaringan internet (Kosasih \& Dkk, 2020). Berdasarkan beberapa definisi tersebut, maka dapat disimpulkan bahwa media sosial adalah sebuah sarana yang digunakan untuk berkomunikasi dan bertukar informasi dengan masyarakat secara luas dengan menggunakan jaringan internet. Media sosial memiliki berbagai macam aplikasi yang bisa dinikmati masyarakat untuk berinteraksi dengan orang lain dalam jaringan. Di antara aplikasi yang bisa diakses antar lain Whatsapp, Instagram, Facebook, Telegram, YouTube, Twitter dan sebagainya.

Pemilihan aplikasi disesuaikan dengan usia pemakai. Bagi generasi muda milenial, penggunaan aplikasi manapun, tidak ada masalah. Namun, bagi generasi tua, khususnya para lansia, penggunaan telepon genggam untuk mengakses berbagai aplikasi bisa menjadi permasalahan tersendiri. Hal inilah yang menjadi salah satu sebab tidak efektifnya penggunaan media sosial sebagai sarana pembinaan di era pandemi. Media sosial seringkali menggunakan teknologi berbasis website atau aplikasi yang mengubah suatu komunikasi ke dalam bentuk dialog yang komunikatif (Fadhilah, 2019). Masyarakat bebas memilih fitur dan aplikasi yang diinginkannya. Asal ada akses internet, semua akan diperoleh dengan mudah.

Perkembangan dan pertumbuhan teknologi informasi dan komunikasi saat ini memang telah mengubah cara interaksi antar individu dalam masyarakat. Internet menciptakan ruang digital baru, menciptakan sebuah ruang kultural yang berbeda dari sebelumnya (Wahyuni, 2017). Penggunaan media sosial tentu memberikan dampak bagi kehidupan masyarakat, baik dampak positif maupun negatif. Dampak positif dari penggunaan media media sosial antara lain memudahkan semua orang untuk berinteraksi dengan orang lain tanpa harus memikirkan jarak dan waktu. Akses-akses informasi dan hiburan dari berbagai penjuru dunia juga sangat mudah diakses. Dengan demikian, adanya media sosial menjadikan berbagai kegiatan yang menuntut adanya interaksi dengan orang lain menjadi lebih efektif dan efisien. Namun di sisi lain, keberadaan media sosial juga berpotensi untuk dimanfaatkan oleh oknum-oknum yang tidak bertanggungjawab untuk melakukan penyimpangan melalui media sosial. Seiring pesatnya kemajuan teknologi, tidak menutup kemungkinan pesat pula menyebarnya berita bohong atau hoax yang bisa menyesatkan. Penyebaran berita yang diakses melalui media sosial cukup dilakukan melalui individu-individu sehingga mempunya tingkat akurasi yang lemah karena mengandung unsur subyektifitas. 
Realitas tersebut berbahaya dan memberikan pengaruh yang kurang baik. Mengingat sebuah informasi harus mempunyai tingkat akurasi yang tinggi dan harus bisa dipertanggungjawabkan secara profesional (Taufik \& Suhaeri., 2020). Salah satu sisi positif dari media sosial adalah berpeluang sebagai sarana pembinaan keagamaan, khususnya di masa pandemi COVID 19. Pembinaan keagamaan dalam bahasa agama pengertiannya sering disamakan dengan istilah dakwah. Dakwah secara bahasa berarti panggilan, seruan atau ajakan. Sedangkan menurut istilah, dakwah mengajak umat dengan cara bijaksana untuk berada di jalan yang benar sesuai yang diajarkan Allah dan Rasul-Nya untuk kemaslahatan di dunia dan akhirat (Karim, 2016). Pada prinsipnya, dakwah merupakan ajakan untuk amar ma'ruf nahi mungkar, yang artinya menyeru untuk melakukan kebaikan dan mencegah dari berbuat kemungkaran.

Pembinaan keagamaan bisa dilakukan dengan berbagai macam metode, antara lain dengan metode ceramah face to face, tanya jawab maupun dengan praktek amaliah. Namun, seiring berkembangnya teknologi informasi dan komunikasi, internet dapat dijadikan media kontemporer untuk menyampaikan dakwah Islam. Internet sebagai media dakwah memiliki kelebihan dalam hal efisiensi, aksebilitas, daya jangkau dan keterbukaan (Rustandi, 2019). Namun penggunaan internet sebagai sarana penyebaran nilai-nilai keagamaan yang bersifat massif, terkadang tidak memiliki filter dalam menyampaikan pesan-pesan keagamaan, baik yang positif maupun negatif. Oleh sebab itu, harus ada upaya untuk menfilter pesan-pesan tersebut agar terhindar dari hoax, ujaran kebencian dan penyesatan (Mazaya, 2019). Membiasakan untuk menyaring informasi khususnya konten keagamaan menjadi sebuah keniscayaan bagi pelaku dakwah dalam menyampaikan pesan-pesan keagamaan.

Pendampingan keagamaan tidak sebatas berupa pemberian materi keagamaan dilakukan dengan metode konvensional berupa ceramah yang bersifat informatif dan edukatif. Namun di sisi lain, pendampingan juga dilakukan dengan memberikan pendampingan kepada masyarakat agar selain kuat secara rohani, juga kuat secara ekonomi. Dalam melakukan pendampingan ekonomi, para dai selaku pendamping ekonomi harus bisa merangkul berbagai pihak untuk bersinergi dalam memberdayakan ekonomi masyarakat, terutama di era pandemic COVID 19. 
Pandemi merupakan wabah yang berjangkit serempak di mana-mana, meliputi daerah geografi yang luas. Wabah COVID-19 adalah bencana yang melanda hampir seluruh Negara (Gugus Tugas, 2019). Berdasarhan hasil penelitian badan kesehatan dunia, World Health Organization (WHO), wabah COVID-19 mengakibatkan terjadinya pandemi global, melanda seluruh dunia. WHO memastikan bahwa lebih dari 210 negara di berbagai benua telah terjangkit virus ini (Susilo \& Dkk, 2020).

Laporan dari WHO mengungkapkan bahwa persebaran virus ini tidak dapat dikendalikan dan sulit sekali diprediksi. Kondisi ini berdampak negatif pada seluruh lini kehidupan, mulai dari psikologis yakni perasaan was-was yang berkepanjangan, kondisi ekonomi yang menurun, kehidupan sosial yang tidak terorganisir, hingga pada proses ibadah dan efektivitas dakwah yang tidak bisa dijalankan secara normal sebgaimana mestinya (Fairozi, 2020). Dengan demikian, era pandemi berarti sebuah kurun waktu dalam sejarah terjadi wabah yeng terjangkit serempak di mana-mana dalam jangkauan wilayah yang luas. Dalam hal ini tidak terbatas di Indonesia, namun juga seluruh dunia. Penyakit ini sangat mengkhawatirkan masyarakat karena penularannya begitu cepat. Saat ini belum ada lembaga dunia dan pemerintah yang bisa memastikan kapan berakhir (Pramono, 2020).

Adanya pandemi COVID-19 sangat mempengaruhi proses pendampingan keagamaan pada masyarakat. Tuntutan menjaga jarak dan menghindari kerumunan menyebabkan gerakan keagamaan yang selama ini sudah berjalan menjadi terhambat. Oleh karena itu penggunaan media sosial sebagai alternatif dalam melakukan pembinaan dan pendampingan keagamaan pada masarakat, khususnya di lereng Merapi.

\section{Tantangan dalam Penyelenggaraan Praktik dengan Media Sosial}

Kecamatan Dukun adalah salah satu kecamatan di Kabupaten Magelang yang berada di kawasan lereng Gunung Merapi. Berdasarkan data dari Biro Pusat Statistik Kabupaten Magelang (Kabupaten Magelang dalam Angka 2019), Kecamatan Dukun berada pada posisi 578 dari permukaan laut (DPL) dengan luas wilayah 53,40 km2. Terdiri dari 15 desa dengan jumlah penduduk 46.416 orang, populasi kepadatan penduduk per km2 mencapai 869 orang. Sebagian wilayahnya berupa persawahan dan perkebunan dengan luas mencapai $4.751 \mathrm{~km} 2$, sehingga sebagian besar penduduk berprofesi sebagai petani dan berkebun. Sementara kondisi geografis didominasi oleh wilayah lereng Gunung Merapi. Kondisi geografis seperti ini sangat mempengaruhi 
pola pikir dan sikap dalam menghadapi permasalahan yang terjadi di masyarakat, termasuk dalam hal kemampuan dalam memanfaatkan media digital serta dalam menerima pembinaan keagamaan baik yang bersifat informatif melalui ceramah maupun yang bersifat pendampingan melalui pemberdayaan masyarakat. Hal ini juga mempengaruhi pola pikir PAI NonPNS selaku Pembina keagamaan untuk menemukan strategi yang tepat untuk mengembangkan kreativitas dalam berinovasi terkait metode yang tepat untuk dipakai dalam melakukan pembinaan keagamaan khususnya di era pandemi, karena justru di era pandemi masyarakat lereng merapi sangat membutuhkan pembinaan keagamaan sebagai penguatan keimanan mereka. Sebagaimana hasil wawancara yang dilakukan terhadap salah satu ketua majlis taklim yang selama ini didampingi oleh salah satu penyuluh dan salah satu tokoh agama yang merupakan penyuluh NonPNS.

"Sudah sekian lama kami tidak diijinkan mengadakan pertemuan berupa pengajian. Padahal dalam suasana normal, setiap hari selasa sore kami mengadakan pengajian yang diisi oleh beberapa ustazd dan penyuluh. Kami percaya adanya virus COVID-19 dan bahayanya bagi warga, namun di sisi lain kami merasa gersang dan butuh siraman rohani untuk menghibur dan menguatkan hati kami dalam menghadapi pandemi. Apalagi saat ini Gunung Merapi di atas kampung kami dalam status siaga. Jadi kami sangat butuh penguatan untuk tetap sabar menghadapi musibah ini". (Nartoat, 2020)

Para pemuka agama dan penyuluh agama sebagai pendamping keagamaan bagi masyarakat juga merasa prihatin atas kondisi pandemi yang belum terlihat ada tanda akan segera berakhir. Mereka merasa kasihan terhadap jamaah yang merindukan suasana normal. Mereka bisa berjamaah, mengikuti kajian bersama.

"Jamaah sering sekali mengirim pesan atau saat bertemu menanyakan kapan bisa mengaji lagi. Memang kehampaan akan nilai-nilai rohani sangat terasa setelah sekian lama tidak ngaji bersama. Padahal biasanya setiap bulan Sya'ban diadakan khataman dengan menggelar pengajian akbar dan penampilan berbagai kesenian. Kini sementara semua harus ditunda". (Khudhori, 2020)

Berhubungan dengan kondisi perekonomian masyarakat lereng merai akibat pandemic COVID 19, berdasarkan hasil wawancara terhadap masyarakat di wilayah lereng Merapi ditemukan berbagai keluhan terkait perekonomian masyarakat yang melemah akibat pandemi COVID-19. Marsono, seorang pedagang yang selama ini mampu berdagang sayuran dengan lancar dengan harga yang cenderung stabil, tiba-tiba harus menelan 
pil pahit disebabkan tertutupnya akses keluar masuknya barang dagangan. Medan yang cukup jauh menuju perkotaan semakin memperparah keadaan. Belum lagi harga-harga yang menurun drastis akibat banyaknya stok sayuran yang mereka kepul dari warga. Padahal roda kehidupan harus terus berjalan. (Wawancara dengan Marsono, warga Ngaglik, Krinjing, Dukun, Magelang, 25 September 2020). Sedangkan Nur Sutras, yang sebelumnya berprofesi yang sama dengan Marsono memilih untuk beralih menekuni pertanian dengan menanam aneka sayuran di sawah (Sutras, 2020).

Keluh kesah terkait kondisi perekonomian di lereng Merapi juga dirasakan oleh Giyanto dan Marsin. Sebagai petani sayuran, keduanya terpaksa harus menelan banyak kerugian akibat pandemi. Penyebabnya tak lain karena harga sayuran yang sangat rendah, karena tertutupnya akses mengirim barang ke kota. Sementara itu harga obat-obatan untuk perawatan tanaman justru merangkak naik (Giyanto, 2020). Adapun Margono Kartin, seorang peternak ayam petelur mengeluhkan sepinya pesanan telur ayam akibat adanya larangan mengadakan kegiatan yang menghadirkan massa, seperti hajatan pernikahan, khitanan maupun pengajian. Akses pengiriman barang keluan dusun menuju kota yang ditutup akibat pandemic COVID-19 semakin memperkecil pemasukan. Akibatnya, harga telurpun turut melemah, sedangkan harga pakan justru merangkak naik (Kartin, 2020). Secara geografis perbandingan antara kawasan lereng Merapi dengan yang berada di kawasan datar.

Tabel 1.Tabel perbandingan kawasan di wilayah Kecamatan Dukun berdasarkan Desa

\begin{tabular}{|l|l|}
\hline KAWASAN LERENG MERAPI & \multicolumn{1}{|c|}{ KAWASAN DATAR } \\
\hline Desa Mangunsoko & Desa Dukun \\
\hline Desa Sewukan & Desa Ngadipuro \\
\hline Desa Sengi & Desa Banyubiru \\
\hline Desa Paten & Desa Banyudono \\
\hline Desa Krinjing & Desa Wates \\
\hline Desa Keningar & Desa Ketunggeng \\
\hline Desa Ngargomulyo & \\
\hline Desa Kalibening & \\
\hline Desa Sumber & \\
\hline
\end{tabular}


Apabila diprosentase maka desa yang berada di kawasan lereng Merapi lebih banyak yakni sebanyak 9 desa $(60 \%)$ dan yang berada di kawasan datar ada 6 desa $(40 \%)$.

Tabel 2 Prosentase Wilayah Berdasarkan Kawasan

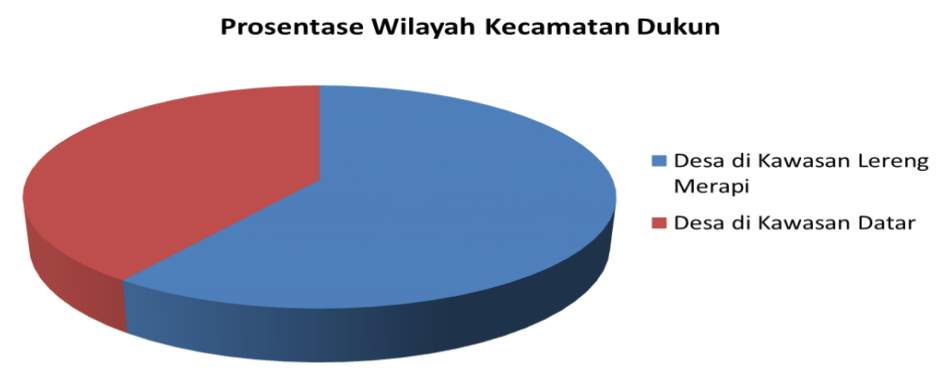

Kondisi tersebut, semua jalan masuk desa kawasan gunung Merapi terpampang papan peringatan Kawasan Rawan Bencana (KRB) letusan Gunung Merapi.

Gambar 1. Papan peringatan Kawasan Rawan Bencana (KRB)

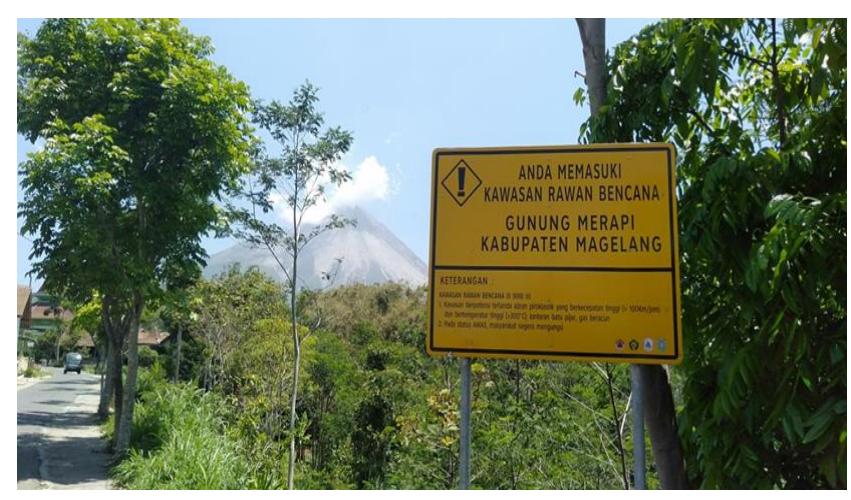

\section{Penggunaan dan Kendalanya Media Sosial sebagai Sarana Dalam}

Pembinaan Keagamaan pada Masyarakat Lereng Merapi di Era Pandemi

Berdasarkan hasil pengamatan dan pengumpulan data terhadap subyek didapati bahwa sebagian besar PAI NonPNS tidak menggunakan media sosial sebagai sarana untuk pembinaan keagamaan pada masyarakat lereng Merapi di era pandemi. Faktor utamanya selain dari pihak PAI NonPNS selaku subyek itu sendiri maupun dari pihak masyarakat selaku obyek. Faktor-faktor itulah yang nanti menjadi hasil dari tujuan penelitian ini yakni kendala yang dihadapi dalam menggunakan media digital sebagai sarana untuk melakukan pembinaan kepada masyarakat lereng Merapi di era pandemi. 
Berdasarkan hasil pengamatan dan analisis yang dilakukan peneliti, maka diperoleh beberapa temuan. Temuan pertama berkaitan dengan kendala yang dihadapi oleh PAI nonPNS selaku pembina yang melakukan pembinaan keagamaan pada masyarakat di era pandemi. Sedangkan temuan kedua berkaitan erat dengan kendala yang dihadapi masyarakat itu sendiri sebagai obyek pembinaan keagamaan.

Kendala dalam penggunaan media sosial sebagai sarana dalam pembinaan keagamaan pada masyarakat lereng Gunung Merapi di era pandemi bagi PAI nonPNS dalam pembinaan keagamaan antara lain terbatasnya fasilitas pendukung untuk mengembangkan metode melalui media sosial, minimnya kemampuan dalam mengoperasikan media, kurangnya akses untuk bisa memproduksi produk digital, kurangnya minat terhadap media sosial karena sebagian besar berlatar belakang pesantren salaf dan sudah terbiasa menggunakan metode ceramah face to face. Selain itu kondisi geografis di lereng Merapi sangat sulit memperoleh signal internet. Sehingga hal ini juga menjadi kendala tersendiri dalam mengakses media sosial sebagai sarana dalam pembinaan keagamaan. Apabila dibuat grafik tentang latar belakang pendidikan PAI Non PNS maka diperoleh hasil yaitu Sarjana 1 orang (12,5\%), SMA 2 orang ( $25 \%$ ), Pondok Pesantren dengan muadalah setara Madrasah Aliyah 2 orang (25\%), Pondok Pesantren belum muadalah (masih setara Madrasah Tsanawiyah) 3 orang (37,5\%).

Tabel 3. Latar belakang pendidikan subyek (PAI nonPNS Kecamatan Dukun)

\begin{tabular}{|c|l|c|c|}
\hline No. & \multicolumn{1}{|c|}{ Jenjang Pendidikan } & Jumlah & Prosentase \\
\hline 1. & Sarjana (S1) & 1 orang & $12,5 \%$ \\
\hline 2. & SMA & 2 orang & $25 \%$ \\
\hline 3. & Ponpes setara MA & 2 orang & $25 \%$ \\
\hline 4. & Ponpes setara MTs & 3 orang & $37,5 \%$ \\
\hline
\end{tabular}

Adapun kendala dari masyarakat sebagai obyek binaan penyuluh adalah minimnya fasilitas untuk mengakses internet, baik karena tidak menggunakan gawai terutama yang sudah lanjut usia maupun keterbatasan ekonomi untuk membeli kuota, keterbatasan sumber daya manusia yang tidak semua mampu mengoperasikan media digital untuk mengakses media sosial dan kondisi geografis di lereng Merapi juga menghalangi proses dalam mengakses signal internet. 


\section{Strategi Pembinaan Keagamaan pada Masyarakat Lereng Merapi di Era Pandemi}

Beberapa kendala dalam menggunakan media sosial sebagai sarana dalam pembinaan keagamaan pada masyarakat lereng Merapi, maka diperoleh strategi yang dipakai para penyuluh supaya masyarakat tetap memperoleh siraman rohani tanpa mengabaikan pemenuhan kebutuhan jasmani serta ketaatan terhadap protokol kesehatan.

Strategi yang digunakan dalam pembinaan keagamaan pada masyarakat lereng Merapi di era pandemi sebagian besar tetap menggunakan metode ceramah face to face dengan tetap mentaati protokol kesehatan terutama di era new normal. Meski pertemuan masih sangat terbatas, misalnya sebatas kultum setelah salat wajib terutama setelah magrib. Untuk kegiatan yang menghadirkan massa dan berpotensi terjadi kerumunan belum dilaksanakan. Mengingat potensi terjadinya kerumunan dan berpotensi terjadinya penularan virus COVID-19. Meski terdapat beberapa kendala dalam penggunaan media digital untuk mengakses media sosial, namun sebagian kecil mencoba menggunakannya khususnya yang bersifat koordinasi dengan pemangku kebijakan dalam upaya pendampingan pembinaan keagamaan. Selain itu pembinaan keagamaan juga dilakukan melalui home visit ke beberapa titik rawan aqidah, mengingat kondisi lemah ekonomi berpotensi melemahkan iman. Kegiatan ini dilakukan bekerjasama dengan Baznas Kabupaten Magelang dan Provinsi Jawa Tengah dengan memberikan bantuan modal untuk pemberdayaan ekonomi.

Berdasarkan hasil penelitian, peneliti menganalisis bahwa tidak semua metode yang digunakan dalam pembinaan keagamaan pada masyarakat di wilayah lereng Merapi melalui media sosial bisa diterapkan. Meskipun di era pandemi ini media sosial merupakan primadona bagi hampir semua kalangan. Seolah-olah media sosial adalah segalanya dan dijamin mampu menjadi solusi dalam menyelesaikan masalah di era pandemi. Salah satunya untuk memenuhi kebutuhan masyarakat lereng Merapi, terutama yang berhubungan dengan kebutuhan rohani berupa pembinaan keagamaan.

Kendala yang ditemukan bagi pembina maupun yang dibina secara garis besar ada kesamaan. Kesamaan itu antara lain dapat dilihat berdasarkan latar belakang pendidikan dari sumber daya manusianya. Antara Pembina dan dan masyarakat lereng merapi sama-sama memiliki keterbatasan dari segi ekonomi karena kedua belah pihak bukanlah pegawai tetap yang 
berpenghasilan besar. Secara formal sesuai Surat Keputusan Pengangkatan para penyuluh, penghasilan mereka masih di bawah Upah Minimum Regional (UMR). Keduanya juga sama-sama terkena dampak dari pandemi COVID-19 terutama di sektor pertanian. Akibat pandemi berkepanjangan, harga hasil pertanian turun drastis. Salah satu penyebabnya karena terbatasnya akses penjualan keluar daerah akibat lockdown. Selain itu, biaya perawatan untuk pertanian dan perkebunan semakin mahal karena harga bibit, pupuk dan obat-obatan pertanian juga ikut naik akibat pandemi.

Analisis berikutnya terkait keterbatasan akses internet karena pengaruh geografis. Memang tidak semua Pembina keagamaan tinggal di wilayah lereng Merapi yang sulit mengakses signal, namun semua penyuluh berkewajiban memberikan pembinaan keagamaan dan pendampingan yang bersifat pemberdayaan sesuai spesialisasinya. Sehingga semua penyuluh juga akan mengalami kendala yang sama. Analisis yang berhubungan dengan strategi menurut peneliti perlu dikaji kembali. Mengingat bahwa pandemi belum selesai. Meskipun ada kebijakan new normal namun harus ditekankan bahwa masyarakat tetap harus waspada, menjaga diri dan lingkungannya dengan tetap menerapkan protokol kesehatan. Selain itu, ancaman bahaya erupsi Gunung Merapi juga menjadi permasalahan baru bagi masyarakat untuk selalu waspada karena status yang masih fluktuatif.

Dengan demikian, Strategi pembinaan keagamaan dengan menggunakan tatap muka, harus benar-benar tertib dengan mematuhi protokol kesehatan. Semua memakai masker dengan benar, menjaga jarak dan sebisa mungkin tidak berkerumun sehingga jumlah hadirinpun hendaknya ada pembatasan. Tersedianya fasilitas cuci tangan menggunakan sabun dan air mengalir juga harus diperhatikan.

Strategi pembinaan keagamaan dengan menggunakan metode home visit dan merangkul berbagai pihak dalam memberdayakan masyarakat sebagai upaya memotivasi mereka untuk bangkit dari keterpurukan akibat pandemi dinilai sangat tepat. Apalagi ada lembaga mitra yang siap berjejaring untuk tidak sekedar memberi ikan tapi juga memberi kail. Bukan bantuan yang bersifat konsumtif namun juga bantuan yang bersifat produktif berupa modal usaha. Modal usaha tersebut ada yang berupa uang tunai, ada juga yang berupa hewan ternak yaitu sapi untuk usaha penggemukan sapi. Perbedaan yang sangat signifikan antara pembina yang mampu menggunakan media digital dengan pembina yang tidak mampu menggunakan media digital mengakibatkan peneliti sulit menemukan sesuatu yang berbeda. 
Hal ini berdampak pada sulitnya menyusun strategi yang dapat dijadikan acuan dalam melakukan pembinaan keagamaan yang lebih tepat untuk diterapakan di masa yang akan datang. Peneliti menemukan latar belakang pendidikan dari obyek yang hampir sama satu sama lain. Demikian pula latar belakang kehidupan ekonomi dan kondisi geografis yang mereka singgahi. Adanya pandemi COVID-19 itu sendiri tidak dapat dipungkiri menjadi kendala dalam melakukan pengumpulan data, karena pasti ada beberapa keterbatasan dalam proses penelitian yang harus ditaati. Hal ini tidak lain karena di masa pandemi ini semua pihak harus tetap waspada akan tertularnya virus COVID-19 termasuk bagi peneliti.

Maka temuan baru yang diperoleh jika dibandingkan dengan penelitian sebelumnya adalah bahwa saat media sosial ditempatkan pada posisi paling strategis sebagai alternatif solusi pendampingan keagamaan di saat pandemi seperti yang dipaparkan Efa Rubawati yang memaparkan tentang tantangan dan peluang dakwah melalui media baru yaitu media sosial, ternyata tidak sepenuhnya bisa berlaku pada masyarakat lereng merapi. Kondisi masyarakat di daerah terpencil seperti lereng Merapi dengan rendahnya kualitas SDM ditambah dengan kondisi geografis yang lemah signal menjadi kendala tersendiri. Hal inlah yang menjadi tantangan atau kelemahan yang mungkin terjadi saat mengandalkan media sosial sebagai sarana pembinaan keagamaan di saat pandemi. Hal itu juga berarti cyberdakwah tidak sepenuhnyaa bisa diterapkan karena kendala tertentu yang tidak diperkirakan sebelumnya.

Penelitian-penelitian yang menempatkan media sosial sebagai solusi yang terbukti efektif agar masyarakat berpikir kritis, kreatif dan positif dengan literasi digital, namun masyarakat di daerah terpencil khususnya leeng merapi belum sepenuhnya mampu berpikir kreatif dalam menghadapi kondisi kritis. Apalagi masyarakat dengan latar belakang SDM rendah, keterbelakangan ekonomi yang minim fasilitas serta kondisi geografis yang sulit terjangkau jaringan internet semakin memperparah kondisi dan jauh dari harapan. Temuan baru berikutnya adalah terkait dengan kondisi para pembina keagamaan. Kondisi pandemi COVID-19 saat ini para pelaksana pembinaan keagamaan diharapkan mampu menggunakan media sosial sebagai salah satu alternatif sarana pembinaan dalam rangka menghindari tatap muka dan kerumunan. Namun kenyataan yang terjadi para penyuluh selaku pembina tidak semua mampu menggunakan media sosial sebagai sarana untuk melaksanakan pembinaan keagamaan di era pandemi. 
Temuan berikutnya adalah adanya alternatif solusi dalam pendampingan keagamaan pada masyarakat lereng Merapi di era pandemi. Alternatif ini diperlukan setelah terbukti penggunaan media sosial sebagai sarana pembinaan keagamaan terbukti tidak efektif, disamping itu juga pembina masih harus menghadapi kenyataan terkait dengan kendala ekonomi baik dari sisi pembina sendiri maupun masyarakat lereng merepi yang masih minim pendapatan, sehingga juga perlu pendampingan lebih lanjut.

\section{Simpulan}

Penggunaan media sosial sebagai sarana dalam pembinaan keagamaan pada masyarakat di lereng merapi di era pandemi menemukan berbagai kendala atau tantangan. Hal tersebut karena berbagai keterbatasan, baik dari pihak penyuluh selaku pembina masyarakat yang memberikan pencerahan rohani maupun bagi masyarakat lereng Merapi selaku binaan dari para penyuluh, sehingga penggunaan media sosial menjadi kurang efektif.

Terdapat berbagai kendala dalam penggunaan media sosial saat melakukan pembinaan keagamaan pada masyarakat lereng Gunung Merapi di era pandemi bagi penyuluh agama yang berhadapan langsung dalam pembinaan keagamaan bagi masyarakat lereng merapi. Kendala tersebut antara lain terbatasnya fasilitas pendukung untuk mengembangkan metode melalui media sosial, minimnya kemampuan dalam mengoperasikan media, kurangnya akses untuk bisa memproduksi produk digital, kurangnya minat terhadap media sosial karena sebagian besar berlatar belakang pesantren salaf dan sudah terbiasa menggunakan metode ceramah face to face serta kondisi geografis di lereng Merapi sangat sulit memperoleh signal internet. Kendalakendala tersebut menjadi tantangan tersendiri bagi para pembina keagamaan dalam melakukan pembinaan keagamaan pada masyarakat lereng merapi khususnya di era pandemi.

Minimnya fasilitas untuk mengakses internet, baik karena tidak menggunakan gawai terutama yang sudah lanjut usia maupun keterbatasan ekonomi untuk membeli kuota, keterbatasan sumber daya manusia yang tidak semua mampu mengoperasikan media digital untuk mengakses media sosial dan kondisi geografis di lereng Merapi juga menghalangi proses dalam mengakses sinyal internet. 
Maka para penyuluh agama menggunakan strategi untuk mengatasi kendala-kendala tersebut, yaitu dalam pembinaan keagamaan pada masyarakat lereng Merapi di era pandemi sebagian besar tetap menggunakan metode ceramah face to face dengan tetap mentaati protokol kesehatan terutama di era new normal. Meski pertemuan masih sangat terbatas, misalnya sebatas kultum setelah salat wajib terutama setelah magrib. Sementara untuk kegiatan yang menghadirkan massa dan berpotensi terjadi kerumunan belum dilaksanakan. Meski terdapat beberapa kendala dalam penggunaan media sosial, namun sebagian kecil berupaya mencoba menggunakannya, khususnya yang bersifat koordinatif dengan pemangku kebijakan dalam upaya pendampingan pembinaan keagamaan. Selain itu juga melalui home visit ke beberapa titik rawan aqidah, mengingat kondisi lemah ekonomi berpotensi melemahkan iman. Kegiatan ini dilakukan bekerjasama dengan Baznas Kabupaten Magelang dan Provinsi Jawa Tengah dengan memberikan bantuan modal untuk pemberdayaan ekonomi.

\section{Referensi}

Fairozi, A. dkk. (2020). Digitalisasi Dakwah; Upaya Meningkatkan Daya Saing Islam Ramah di Era Pandemi. Jurnal Bimas Islam, 13(2).

Giyanto. (2020). Wawancara.

Herawati, A. (2017). Peran Dai dalam Pemberdayaan Umat melalui Green Dakwah. Digital Library Universitas Muhammadiyah Yogyakarta.

Ismail, N. (2015). Metodologi Penelitian untuk Studi Islam Panduan PRaktis dan Diskusi Isu. Samudra Biru.

Karim, A. (2016). Dakwah Melalui Media: Sebuah Tantangan dan Peluang. Tabsyir: Jurnal Komunikasi Penyiaran Islam, 4(1).

Kartin, M. (2020). Wawancara.

Khilmiyah, A. (2016). Metode Penelitian Kualitatif. Samudra Biru.

Khudhori, M. (2020). Wawancara.

Kosasih, K., \& Dkk. (2020). Literasi Media Sosial dalam Permasyarakatan Moderasi Beragama dalam Situasi Pandemi COVID-19. Digital Library UIN Sunan Gunung Djati.

Mazaya, V. (2019). Cyberdakwah sebagai Filter Penyebaran Hoax. Islamic Communication Journal, 4(1).

Moloeng, L. (2013). Metode Penelitian Kualitatif. PT Remaja Rosdakarya.

Mulyana, D. (2013). Metodologi Penelitian Kualitatif Paradigma Baru Ilmu Komunikasi dan Ilmu Sosial Lainnya. PT Remaja Rosdakarya.

Nartoat. (2020). Wawancara. 
Pramono, G. A. (2020). Telaah Kritis Kejahatan Penyebaran Hoax saat Pandemi COVID-19. Jurnal Ilmu Hukum, 9(2).

Rubawati, E. (2018). Media baru: Tantangan dan Peluang Dakwah. Jurnal Studi Komunikasi, 2(1).

Rustandi, R. (2019). Cyberdakwah: Internet sebagai Media dalam Sistem Komunikasi Dakwah Islam. Nalar: Jurnal Peradaban dan Pemikiran Islam, 3(2).

Susilo, A., \& Dkk. (2020). Coronavirus Disease 2019: Tinjauan Literatur Terkini. Jurnal Penyakit Dalam Indonesia, 7(1).

Sutras, N. (2020). Wawancara.

Taufik, C. M., \& Suhaeri. (2020). Urgensi Literasi dalam Suasana Chaos. Jurnal Ensains, 3(2).

Taufiq, F. \& Utama, L. W. P. (2018). Media Sosial dan Gerakan Sosio-Politik Umat Islam di Indonesia. Fikrah: Jurnal Ilmu Aqidah dan Studi Keagamaan, 6(2).

Wahyuni, D. (2017). Agama sebagai Media dan Media sebagai Agama. Jurnal Ilmu Agama., 18(2).

Wening, A. A. (2020). Kasus COVID-19 di Magelang Naik Signifikan, ini Penyebabnya. semarang.bisnis.com.

https://semarang.bisnis.com/read/20200928/535/1297310/kasus-COVID-19-dimagelang-naik-signifikan-ini-penyebabnya 
This page intentionally left blank 